RASĀYAN J. Chem.

Vol. 12 | No. 4 |1956 - 1963| October - December | 2019 ISSN: 0974-1496 | e-ISSN: 0976-0083 | CODEN: RJCABP

RJC http://www.rasayanjournal.com http://www.rasayanjournal.co.in

\title{
UTILIZATION OF UNWANTED TERRESTRIAL WEEDS FOR REMOVAL OF DYES
}

\author{
A. Singh ${ }^{1}$, S. Kumar ${ }^{1}$, V. Panghal ${ }^{1}$, S. S. Arya ${ }^{2}$ and S. Kumar ${ }^{1, *}$ \\ ${ }^{1}$ Department of Environmental Sciences, Maharshi Dayanand University, \\ Rohtak-124001, Haryana, India \\ ${ }^{2}$ Department of Botany, Maharshi Dayanand University, Rohtak-124001, Haryana, India \\ *E-mail: sunilevs@yahoo.com
}

\begin{abstract}
Human welfare is adversely affected by unwanted and undesirable plants, which convert the useable land into a wasteland. The present study was an attempt to utilize unwanted weeds as a resource with the objective to evaluate the removal efficiency of two low cost adsorbents named as Raw Parthenium hysterophorus (RPH) and Raw Saccharum munja (RSM) for adsorption of dyes like Congo red (CR), Methylene blue (MB) and Crystal violet (CV). The batch study was carried out to study the impacts of various parameters like $\mathrm{pH}$, adsorbent dose, initial dye concentration, contact time and shaking speed. The maximum adsorption for CR was $86 \%$ by RPH, MB was $98 \%$ and CV was $97 \%$ by RSM at dose $1 \mathrm{~g} / 100 \mathrm{ml}, 150 \mathrm{rpm}$, dye concentration 50ppm, time 120 minutes and temperature $25^{\circ} \mathrm{C}$ but optimized $\mathrm{pH}$ was varied according to dyes and type of adsorbents, it was ranged from 4 to 10 . Adsorption isotherms were applied on the experimental data and found to be Freundlich isotherm was well fitted for RSM and RPH during MB dyes adsorption $\left(\mathrm{r}^{2}=0.892 \& 0.858\right)$ as compared to CR and CV dyes. Low-cost adsorbents have potential to adsorb dyes from wastewater and show applicability in wastewater treatment process.

Keywords: Adsorption, Wastewater, Congo Red, Methylene Blue, Crystal Violet, Adsorbent.
\end{abstract}

CRASĀYAN. All rights reserved

\section{INTRODUCTION}

Water pollution by dyes is becoming a worldwide problem nowadays because a large quantity of dyeing effluent is discharged into water bodies. Various industries including textiles, food, plastic, cosmetics, rubber, paper and pulp use chemicals during the processing of raw material, i.e. Dyes, organic colored compounds that impart color to various substrates. There is various type of dyes used in textile industries like reactive dye, direct dye, basic dye, acid dye, azo dye, mordant dye, disperse dye, vat dye and sulphur dye. ${ }^{1}$ These dyes contain aromatic structure which provides stability to them, so they are nonbiodegradable in nature. ${ }^{2}$ The colored water caused due to dyes impair aquatic ecosystem as sunlight could not penetrate through colored water and affects photosynthetic activity. Dyes are also known to be mutagenic, carcinogenic and toxic in nature, ${ }^{3}$ so there must be proper method for dye removal in textile industries as these are the main source of dye effluent discharge in nearby water bodies.

Various remediation processes have been employed for dye removal namely, nano-filtration, oxidation process, ion exchange, ozonation, ultrafiltration and coagulation, but these are not cost-effective and difficult to operate. Due to some drawbacks of remediation processes, adsorption process found to be best process due to its low cost, low maintenance and low generation of by-products. The highly used conventional adsorbent is activated carbon due to more availability of porosity, surface area and high adsorption rate. Nowadays, various non-conventional adsorbents are used in adsorption process depending on their low cost and abundance in nature. Low-cost adsorbents require little processing and found abundantly in nature. The various low cost adsorbents have been investigated by researchers like agricultural waste, ${ }^{4}$ banana peel, ${ }^{5}$ Ficus carica, ${ }^{6}$ apple peels, ${ }^{7}$ apricot stone, ${ }^{8}$ bagasse fly ash, ${ }^{9}$ peat,${ }^{10}$ abundant weeds, ${ }^{11}$ walnut shell, ${ }^{12}$ soya waste, ${ }^{13}$ hen feather, ${ }^{14}$ oil palm midrib, ${ }^{15}$ sugarcane baggase, ${ }^{16}$ Typha angustifolia, ${ }^{17}$ natural zeolites, ${ }^{18}$ sewage sludge,${ }^{19}$ etc. The objective of the present work is to study the adsorption of congo red (CR), methylene blue (MB) and crystal violet (CV) on dead biomass of weeds

Rasayan J. Chem., 12(4), 1956-1963(2019)

http://dx.doi.org/10.31788/RJC.2019.1245401

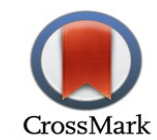


RASĀYAN J. Chem.

Vol. 12 | No. 4 |1956 - 1963| October - December | 2019

Parthenium hysterophorus and Saccharum munja. These weeds cause adverse effects on environment and human health. Pollens of these also cause respiratory problems and allergies. These are explored for useful purposes, i.e., removal of dyes from wastewater.

\section{EXPERIMENTAL}

Adsorbent Preparation

In this study, plants Parthenium hysterophorus and Saccharum munja were used as adsorbent, collected from a nearby area of Rohtak city for removal of dye from aqueous solution. To remove dirt and other impurities, washing was done by tap water followed by distilled water. Initially dead biomass of these plants was dried under sunlight then followed by drying in oven at $60^{\circ} \mathrm{C}$ for 24 hours. Plants were crushed to make powder and sieved. These were washed with $1 \%$ formaldehyde to remove color then dried and stored in airtight containers. Characterizations of adsorbents have been done according to Allen. ${ }^{20}$

\section{Dye Solution}

The analytical grade dyes Congo red (CR), Methylene blue (MB), Crystal violet (CV) purchased from Central Drug House (P) Ltd. were used. Stock solution $(1000 \mathrm{mg} / \mathrm{l})$ of dyes was made by dissolving $1 \mathrm{~g}$ of dyes into 1 liter distilled water and serial dilutions were made with distilled water to prepare working solutions of different concentrations.

\section{Batch Adsorption Study}

Adsorption experiments were done to assess the effects of various parameters such as $\mathrm{pH}$, adsorbent dose, contact time, the concentration of dye and shaking rate. To examine the effect of $\mathrm{pH}$, time was kept $1 \mathrm{hr}$, whereas dose was $0.5 \mathrm{~g} / 100 \mathrm{ml}$ at $25^{\circ} \mathrm{C}$ with $150 \mathrm{rpm}$ and $\mathrm{pH}$ varied from 3 to 10 . In case of optimization of dose, known amount of adsorbent doses were agitated with $100 \mathrm{ml}$ dye solution of $100 \mathrm{ppm}$ for $\mathrm{MB}$ and $\mathrm{CV}$, whereas $20 \mathrm{ppm}$ for CR was taken in $250 \mathrm{ml}$ conical flasks at a speed of $150 \mathrm{rpm}$ at $25^{\circ} \mathrm{C}$ for 1 hour. To assess the impact of contact time, the study was conduct at $0.5 \mathrm{~g} / 100 \mathrm{ml}$ dose, $\mathrm{pH} 7$ (RSM) and $\mathrm{pH} 4$ (RPH) for CR, pH 10 (RSM) and $\mathrm{pH} 5(\mathrm{RPH})$ for MB, pH 10 (RSM) and 8 (RPH) for CV at 150rpm and $25^{\circ}$. The effect of initial concentration and rpm was assessed by varying the concentration from 20 to $250 \mathrm{mg} / 1$ and rotation from 50 to 250 at optimized conditions. After desired contact time, conical flasks were removed and allowed to settle down the adsorbent. The samples were filtered out using Whatman filter paper and filtrate was measured by using UV-visible spectrophotometer at $497 \mathrm{~nm}$ for CR, $590 \mathrm{~nm}$ for $\mathrm{CV}$ and $665 \mathrm{~nm}$ for MB. In this study, parameters included were $\mathrm{pH}(3-10)$, dose $(0.2-1.2 \mathrm{~g})$, initial dye concentration $(50-250 \mathrm{mg} / \mathrm{l})$, contact time $(15-120 \mathrm{~min})$ and $\mathrm{rpm}(50-250)$ by varying one at a time and keeping others constant. The removal percentage of dye was calculated as removal efficiency:

$$
\text { Removal }(\%)=\left(\left(\mathrm{C}_{0}-\mathrm{C}_{\mathrm{e}}\right) / \mathrm{C}_{0}\right) \times 100
$$

Where, $\mathrm{C}_{0}$ and $\mathrm{C}_{\mathrm{e}}$ are initial and final concentration $(\mathrm{mg} / \mathrm{l})$ of dye before and after adsorption, respectively. The amount of dye adsorbed on the surface of adsorbate was calculated as follows:

$$
\mathrm{q}_{\mathrm{e}}(\mathrm{mg} / \mathrm{g})=\left(\mathrm{C}_{0}-\mathrm{C}_{\mathrm{e}}\right) \mathrm{V} / \mathrm{x}
$$

Where, $\mathrm{C}_{0}$ and $\mathrm{C}_{\mathrm{e}}$ are initial and final concentrations of the dye adsorbed $(\mathrm{mg} / \mathrm{l}), \mathrm{V}$ is the volume of the dye solution (Litre), $\mathrm{q}_{\mathrm{e}}$ is the amount of dye adsorbed at equilibrium and $\mathrm{x}$ is the weight of the adsorbent(g).

\section{Adsorption Isotherm}

It is a batch equilibrium test that provides data relating to adsorbent adsorbed per unit weight to the amount of adsorbent in the solution. To describe the adsorption isotherm, Freundlich model was applied. Freundlich isotherm: It assumes the adsorption of dye on the heterogeneous surface and there is no restriction to the formation of monolayer. ${ }^{21}$ The linear form of the Freundlich isotherm is described by:

$\log \mathrm{q}_{\mathrm{e}}=\log \mathrm{K}_{\mathrm{F}}+1 / \mathrm{n} \log \mathrm{C}_{\mathrm{e}}$

Where, $C_{e}\left(\mathrm{mg} \mathrm{L}^{-1}\right)$ is the equilibrium concentration, $\mathrm{q}_{\mathrm{e}}(\mathrm{mg} / \mathrm{g})$ is the amount of dye adsorbed at equilibrium by the adsorbent, $\mathrm{K}_{\mathrm{F}}(\mathrm{mg} / \mathrm{g})$ and $\mathrm{n}$ are constants representing the adsorption capacity and intensity of adsorption. 
RASĀYAN J. Chem.

Vol. 12 | No. 4 |1956 - 1963| October - December | 2019

\section{Characterization of Adsorbent}

\section{RESULTS AND DISCUSSION}

The characterization of adsorbents is shown in Table-1. Raw Parthenium hysterophorus (RPH) was found slightly acidic very near to neutral point whereas, raw Sachharum munja (RSM) was more acidic in nature. The bulk density of RPH and RSM was found to be $0.353 \mathrm{~g} / \mathrm{cm}^{3}$ and $0.169 \mathrm{~g} / \mathrm{cm}^{3}$, respectively, which indicate that adsorbents were lighter in weight and contain more particle per gram while the particle density was noted as $0.383 \mathrm{~g} / \mathrm{cm}$ and $0.224 \mathrm{~g} / \mathrm{cm}^{3}$, respectively. The adsorbents solubility in water was recorded as $4.2 \%$ and $5.9 \%$ for RPH and RSM, respectively. Similarly, the solubility in acid was recorded as $7.5 \%$ and $8.4 \%$ for RPH and RSM, respectively.

Table-1: Characterization of Adsorbents Prepared from Weeds.

\begin{tabular}{c|c|c}
\hline Parameters & P.hysterophorus & S.munja \\
\hline $\mathrm{pH}$ & 6.15 & 5.70 \\
\hline $\begin{array}{c}\text { Bulk density } \\
\mathrm{g} / \mathrm{cm}^{3}\end{array}$ & 0.353 & 0.169 \\
\hline Particle density g/cm ${ }^{3}$ & 0.383 & 0.224 \\
\hline Solubility in water (\%) & 4.2 & 5.9 \\
\hline Solubility in acid (\%) & 7.5 & 8.4 \\
\hline Porosity(\%) & 7.83 & 22.55 \\
\hline
\end{tabular}

\section{Effect of pH}

The $\mathrm{pH}$ is the main parameter in the adsorption of dye. The removal percentage of various dyes at different $\mathrm{pH}$ is depicted in Fig.-1. The effect of $\mathrm{pH}$ was studied by varying $\mathrm{pH}$ from 3 to 10 . The experiment was carried out by taking $0.5 \mathrm{~g}$ of adsorbent agitating with $20 \mathrm{ppm}$ of Congo red (CR) and $100 \mathrm{ppm}$ of both Methylene blue (MB) and Crystal violet (CV) dyes at a speed of 150rpm for 1hour at $25^{\circ}$. For CR, Raw Saccharum munja (RSM) showed maximum removal $61.7 \%$ of dye at $\mathrm{pH} 7$ and Raw Parthenium hysterophorus (RPH) showed $86.9 \%$ removal at $\mathrm{pH} 4$.

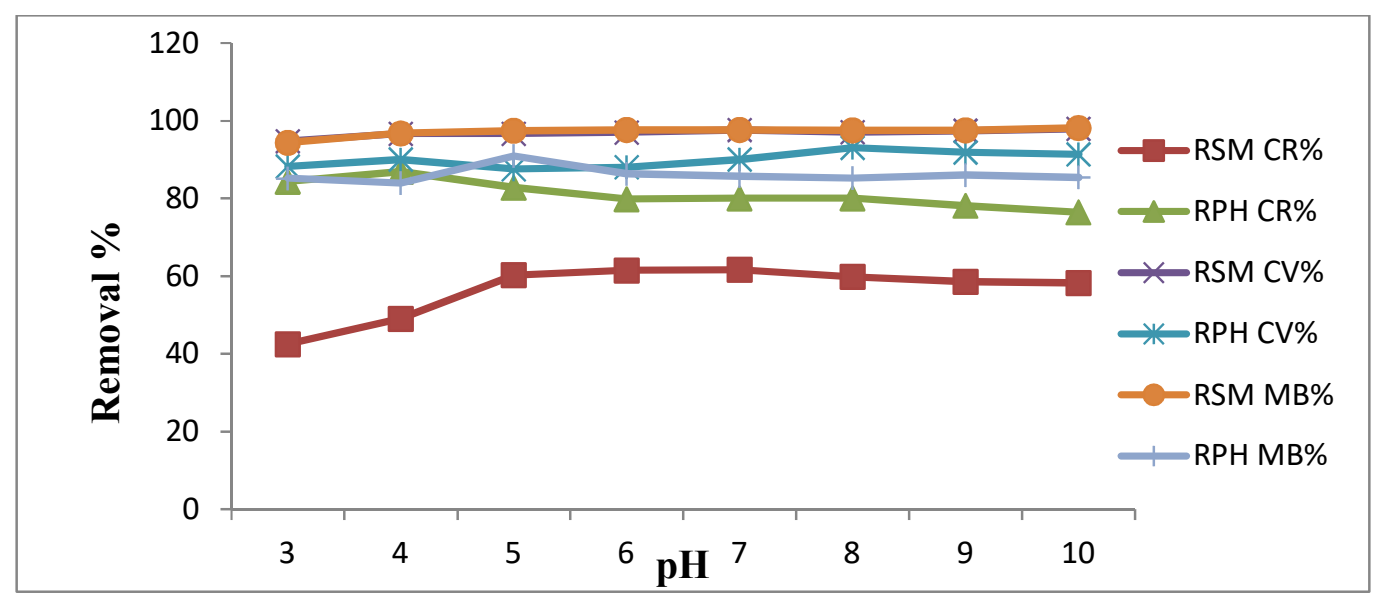

Fig.-1: Effect of $\mathrm{pH}$ on Removal \% of Dye: Initial Dye Concentration CR(20mg/l), MB and CV (100mg/l), Dose $(0.5 \mathrm{~g})$, Contact Time (60min), rpm $(150)$ and Temperature $\left(25^{\circ} \mathrm{C}\right)$.

The maximum adsorption by $\mathrm{CR}$ at $\mathrm{pH} 7$ could be due to a higher $\mathrm{pH}$, the negatively charged sites were not favorable for dye adsorption due to electrostatic repulsion. ${ }^{22}$ At lower $\mathrm{pH}$ than 4 , dye adsorption would not favor because CR changes red to blue. Congo red showed maximum efficiency removal in neutral $\mathrm{pH}$ and minimum in basic $\mathrm{pH}$ due to presence of $\mathrm{OH}^{-}$ions compete for adsorption sites with dye anions. For MB, RSM showed maximum removal $98.2 \%$ of dye at $\mathrm{pH} 10$ and $\mathrm{RPH} 91 \%$ showed at $\mathrm{pH} 5$. $\mathrm{MB}$ is cationic dye, when it dissolves in water gives positively charged ions. Adsorption of cationic adsorbate like MB opposed by positively charged surface of adsorbent in acidic medium. But when we increase the $\mathrm{pH}$ of solution, the surface of adsorbent acquires the negative charge which enhances the adsorption process of $\mathrm{MB}$ due to increasing in electrostatic attraction among the negative charges 1958 
RASĀYAN J. Chem.

Vol. 12 | No. 4 |1956 - 1963| October - December | 2019

adsorbent and positively charged dye. ${ }^{23-24}$ For CV, RSM and RPH showed maximum dye removal 98 and $93.1 \%$ at $\mathrm{pH} 10$ and $\mathrm{pH} 8$, respectively. It is evident from the results that there was significant variation in optimum $\mathrm{pH}$ for various dyes.

\section{Effect of Dose}

The adsorbent dose is also an important factor as it shows the adsorption capacity of adsorbent at initial concentration of adsorbate solution. As amount of adsorbent increases, adsorption rate increases because number of active sites for adsorption increases with increase in amount of adsorbent dose. The effect of adsorbent dose was studied by varying dose $0.2 \mathrm{~g}$ to $1.2 \mathrm{~g}$ at optimized $\mathrm{pH}$, concentration $20 \mathrm{ppm}$ of $\mathrm{CR}$ and $100 \mathrm{ppm}$ for both $\mathrm{MB}$ and $\mathrm{CV}$ at a speed of $150 \mathrm{rpm}$ for 1 hour at $25^{\circ} \mathrm{C}$. Fig.2 illustrated that as amount of adsorbent dose increases from $0.2 \mathrm{~g} / 100 \mathrm{ml}$ to $1.2 \mathrm{~g} / 100 \mathrm{ml}$ the removal percentage increased from $22.9 \%$ to $93.7 \%$ for RSM, $33 \%$ to $67.3 \%$ for RPH for Congo red, $77.8 \%$ to $89.4 \%$ for RSM, $67.2 \%$ to $80.6 \%$ for RPH for Crystal violet and $76 \%$ to $89 \%$ for RSM, $69.7 \%$ to $89.5 \%$ for RPH for MB. Both adsorbents showed equilibrium saturation for dye removal at $1 \mathrm{~g} / 100 \mathrm{ml}$ of adsorbent.

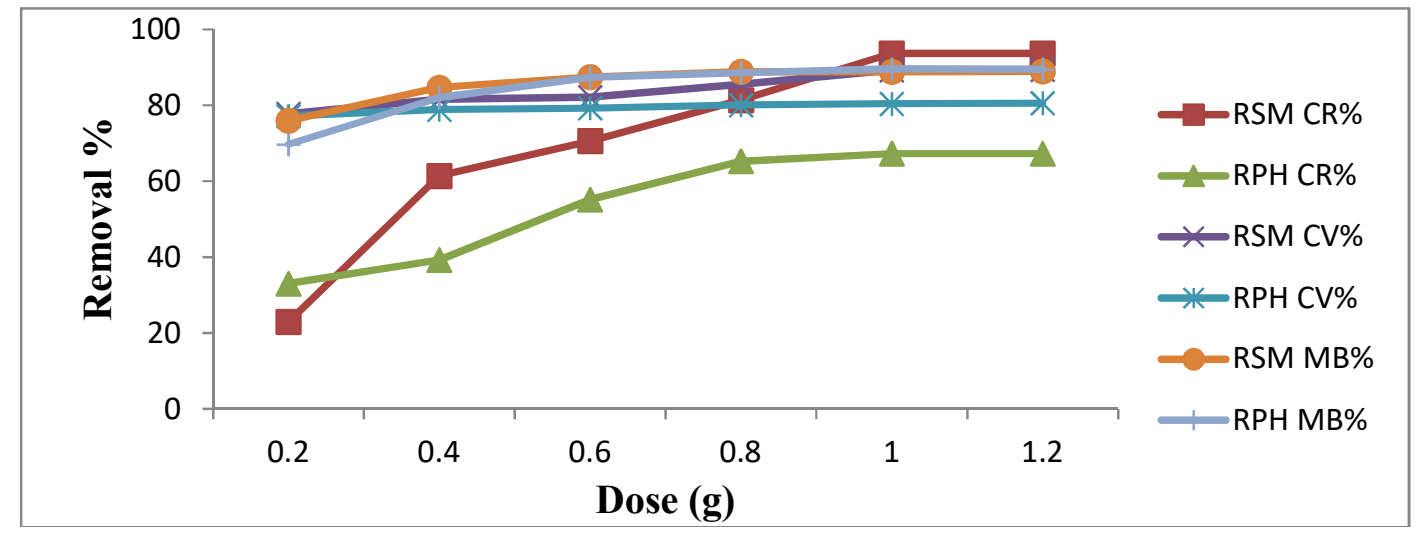

Fig.-2: Effect of Adsorbent Dose on removal \% of Dye: Initial Dye Concentration CR(20ppm), MB and CV $(100 \mathrm{ppm})$, Contact Time (60min), rpm $(150)$ and Temperature $\left(25^{\circ} \mathrm{C}\right)$ at Optimized $\mathrm{pH}$.

\section{Effect of Initial Dye Concentration}

Figure-3 illustrated the effect of initial dye concentration on adsorption of dyes. The batch study was carried out by varying initial dye concentration from 50 to $250 \mathrm{ppm}$ by taking $1 \mathrm{~g}$ of adsorbent agitating in a shaker for 1 hour at $25 \mathrm{C}$ with shaking speed of $150 \mathrm{rpm}$. The result revealed that adsorption was maximum at $50 \mathrm{ppm}$ and after that adsorption percentage decreases. It is attributed to more availability of the adsorption sites ${ }^{25}$ and adsorption sites become saturated with increased concentration of dyes. The maximum removal of CR by RSM and RPH were observed as 94.6 and $84.7 \%$, respectively. For MB, maximum removal was found to be 93.9 for RSM and $90.4 \%$ for RPH, while in case of CV removal was 91.4\% for RSM, 90.1\% for RPH respectively.

\section{Effect of Contact Time}

Figure-3 shows the effect of contact time on adsorption of dyes by RSM and RPH. Contact time is the time which ensures the duration of agitation time which is sufficient for the adsorption process to reach equilibrium. ${ }^{26}$ The rate of adsorption increases with increase in time and becomes constant after attaining equilibrium. This is attributed to the availability of adsorption sites followed by slower adsorption by attaining saturation level after equilibrium. RSM and RPH showed maximum removal percentage at 120 minutes by taking $20 \mathrm{ppm}$ of $\mathrm{CR}$ and $100 \mathrm{ppm}$ for $\mathrm{MB}$ and $\mathrm{CV}, 0.5 \mathrm{~g} / 100 \mathrm{ml}$ of adsorbent dose at $150 \mathrm{rpm}$, $25^{\circ} \mathrm{C}$ temperature. Results revealed that maximum removal of CR by RSM and RPH was found to be 87.36 and $71.11 \%$, respectively. Similarly, MB showed maximum removal of 92.1 and $85.56 \%$ by RSM and RPH, respectively. While, removal for CV was found to be 86 and $84.2 \%$ for RSM and RPH, respectively. The various dyes and adsorbents showed the Equilibrium/ saturated time at one hour. 
RASĀYAN J. Chem.

Vol. 12 | No. 4 |1956 - 1963| October - December | 2019

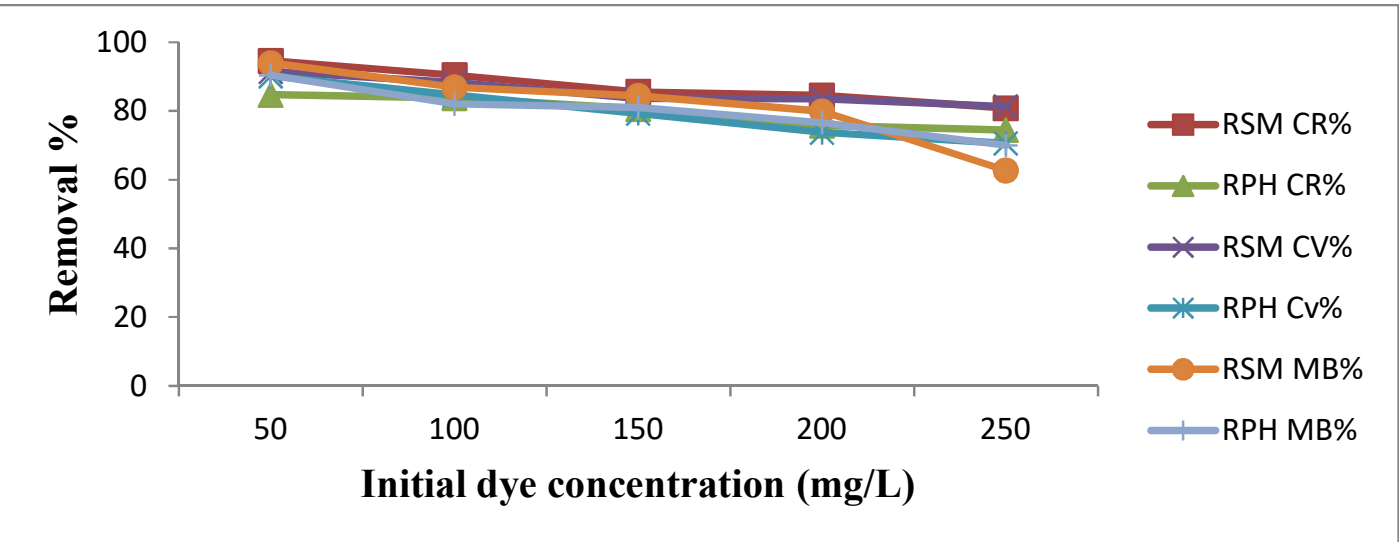

Fig.-3: Effect of Initial Dye Concentration on Dye Removal \%: Dose (0.5g), Contact Time (60min), rpm (150) and Temperature $\left(25^{\circ} \mathrm{C}\right)$ at Optimized $\mathrm{pH}$.

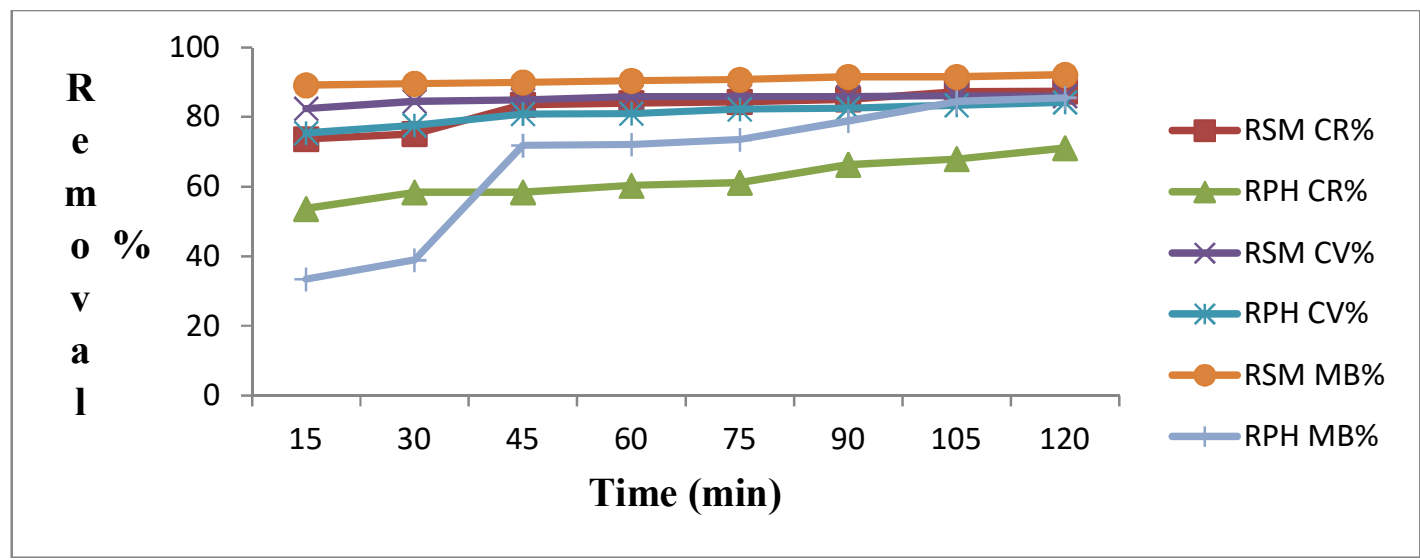

Fig.-4: Effect of Contact Time on Dye Removal \%: Dose (0.5g), Concentration (20ppm for CR and $100 \mathrm{ppm}$ for MB

\section{Effect of RPM} and $\mathrm{CV}), \mathrm{rpm}(150)$ and Temperature $\left(25^{\circ} \mathrm{C}\right)$ at optimized $\mathrm{pH}$.

The effect of rpm on dye removal as shown in Fig.-5. It showed that the maximum removal percentage for three dyes had been achieved at $250 \mathrm{rpm}$, while equilibrium conditions were attained at $150 \mathrm{rpm}$. It is attributed that after a particular shaking rate, the removal of dye became saturated due to less availability of adsorption sites. RSM and RPH showed maximum removal of 95.8 and $80.6 \%$ for CR, respectively and similarly, 91.1 and $89.9 \%$ for RSM and RPH for MB. While in case of CV, the maximum removal was found to be 88.7 and $85.5 \%$ for RSM and RPH, respectively.

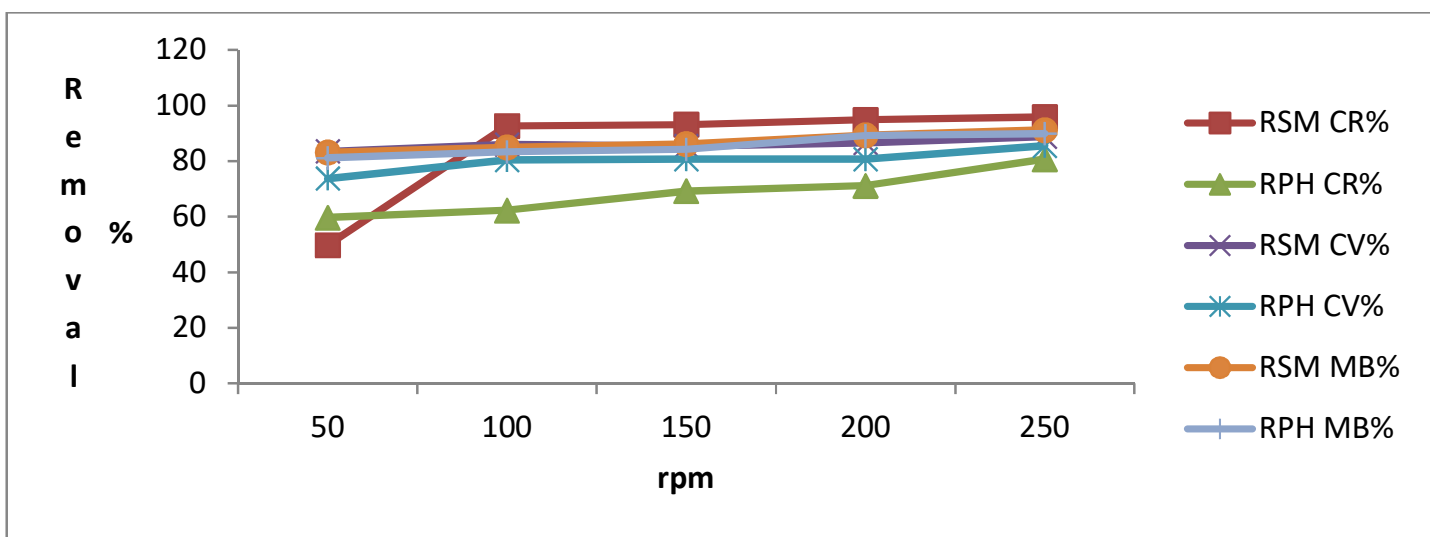

Fig.-5: Effect of rpm on Dye Removal \%: Dose (1g), Concentration (50ppm), rpm (150) and Temperature (25C) at Optimized $\mathrm{pH}$.

1960 
RASĀYAN J. Chem.

Vol. 12 | No. 4 |1956 - 1963| October - December | 2019

\section{Adsorption Isotherm}

Adsorption isotherm was conducted in this study to examine the adsorption mechanism. Freundlich isotherm was better fitted for $\mathrm{MB}$ as compared to $\mathrm{CR}$ and $\mathrm{CV}$. The $\mathrm{n}$ value shows heterogeneity of the adsorbent surface and also depict favourable adsorption of dye. The $\mathrm{K}_{\mathrm{f}}$ value suggests the dye-binding affinity of adsorbent. $\mathrm{R}^{2}$ value indicates the equilibrium relationship between the amount of adsorbed dye and their equilibrium concentration in the solution.

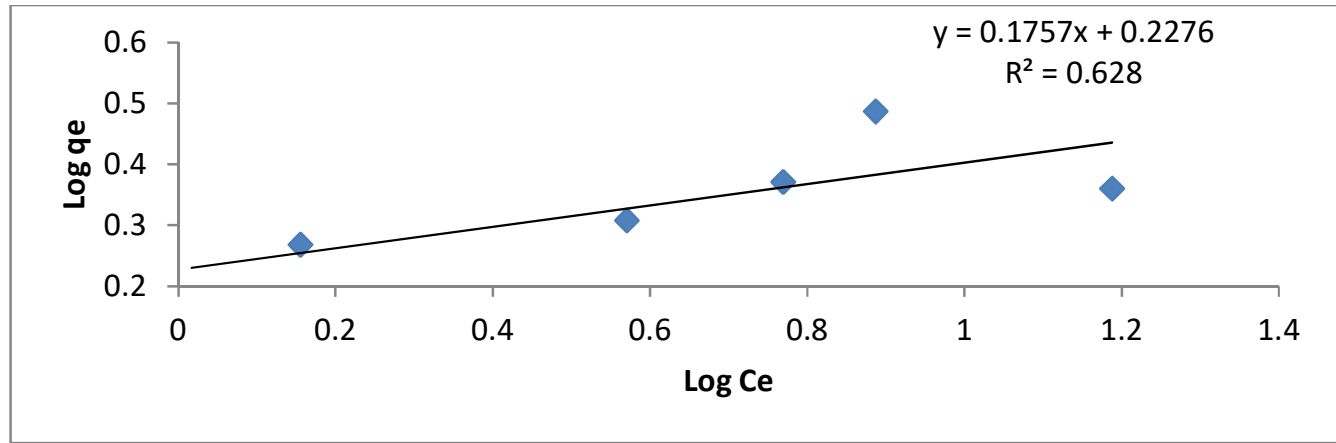

Fig.-6: Freundlich Plot for RSM on CR

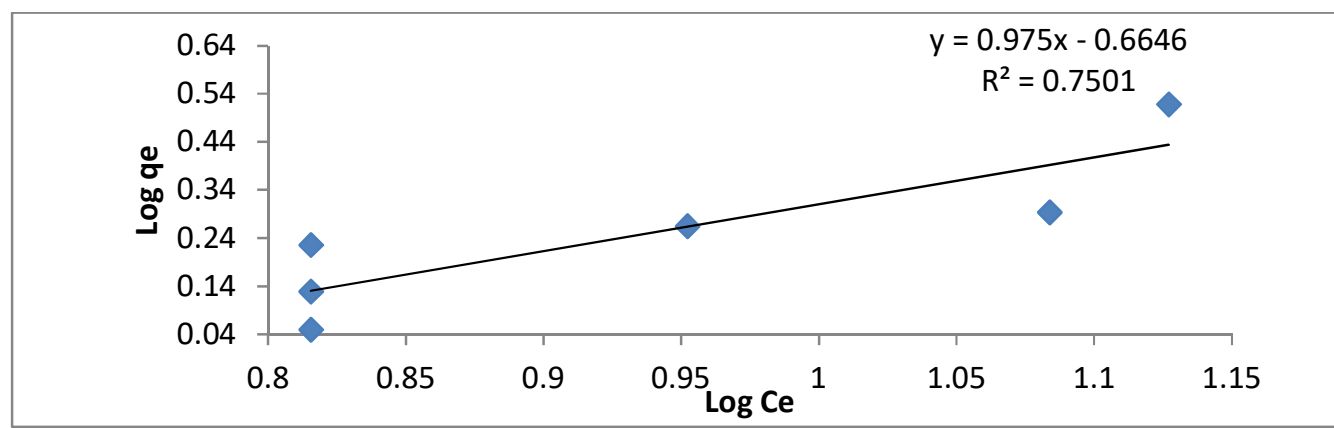

Fig.-7: Freundlich Plot of RPH on CR

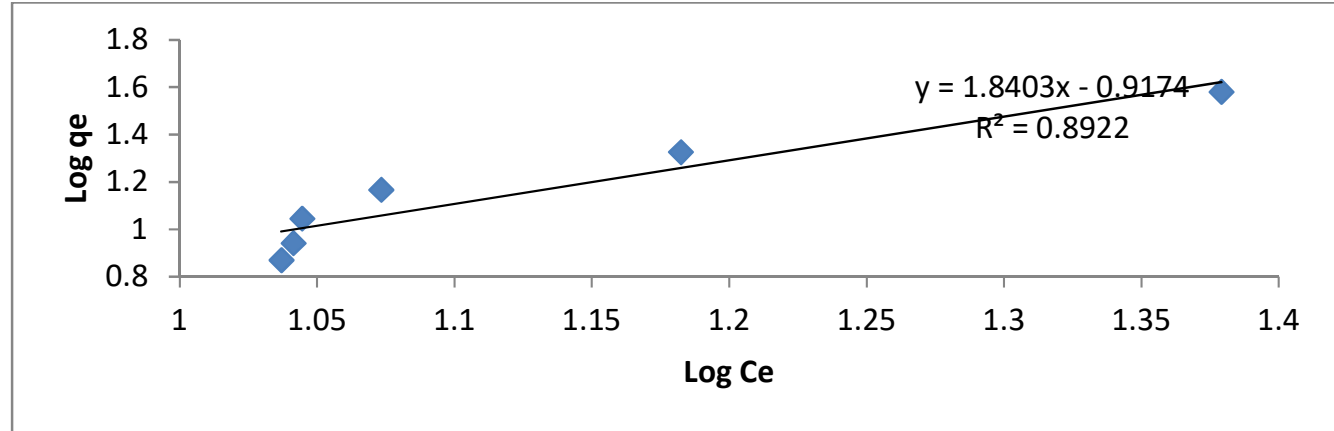

Fig.-8: Freundlich Plot of RSM on MB

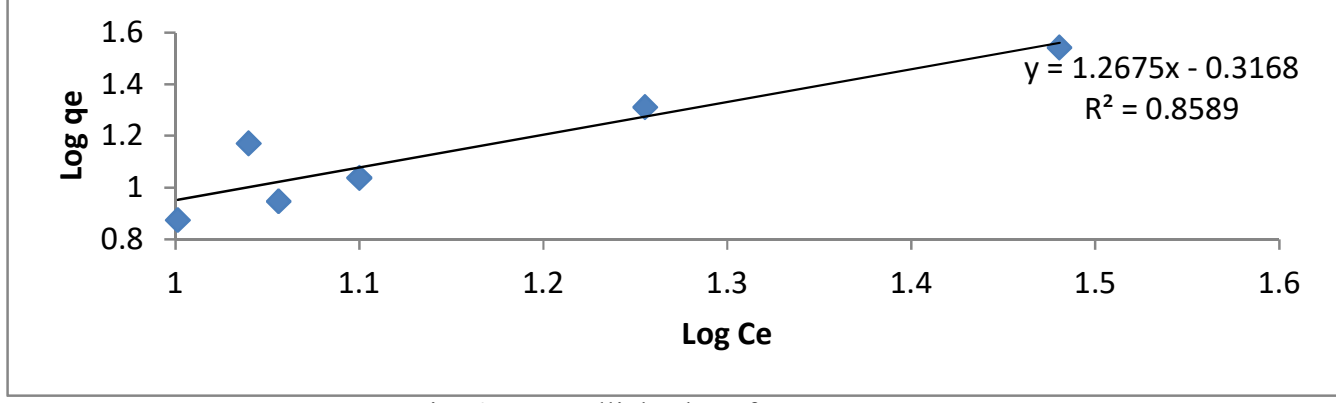

Fig.-9: Freundlich Plot of RPH on MB 
RASĀYAN J. Chem.

Vol. 12 | No. 4 |1956 - 1963| October - December | 2019

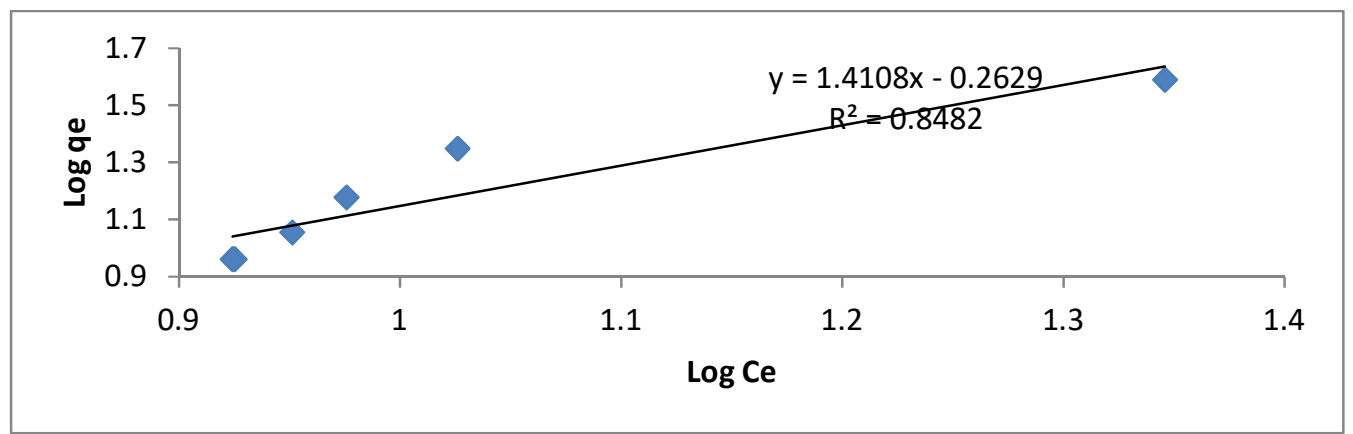

Fig.-10: Freundlich Plot for RSM on CV

Table-2: Rate Constant of Freundlich Isotherm for Different Dyes CR, MB and CV.

\begin{tabular}{c|c|c|c|c}
\hline Dye & Adsorbent & $\mathrm{K}(\mathrm{mg} / \mathrm{g})$ & $\mathrm{N}$ & $\mathrm{R}^{2}$ \\
\hline Congo red (CR) & Saccharum munja & 1.686 & 5.71 & 0.628 \\
& Parthenium hysterophorus & 4.61 & 1.02 & 0.750 \\
\hline Methylene blue & Saccharum munja & 8.26 & 0.54 & 0.892 \\
(MB) & Parthenium hysterophorus & 2.07 & 0.78 & 0.858 \\
\hline Crystal violet (CV) & Saccharum munja & 1.82 & 0.70 & 0.848 \\
\hline
\end{tabular}

\section{CONCLUSION}

Colored effluent is a great threat to the freshwater bodies and needs to treat before discharge. It was found that powder prepared from Raw Parthenium hysterophorus (RPH) and Raw Saccharum munja (RSM) are good adsorbents for removal of dyes and can be used in wastewater treatment. On the other hand, Parthenium hysterophorus and Saccharum munja are unwanted weeds, which degrade the land quality and create various health problems in human beings. So, this study was an attempt to utilize these unwanted plants for dyes removal. The optimized parameters for maximum adsorption of Congo Red, Methylene Blue and Crystal Violet were found to be dose (1g), rpm (150), time (120minutes), temperature $\left(25^{\circ} \mathrm{C}\right)$, dye concentration $(50 \mathrm{ppm})$ for both adsorbents. For Congo Red, RSM showed maximum removal of dye at $\mathrm{pH} 7$ and $\mathrm{RPH}$ showed at $\mathrm{pH} 4$, while optimum $\mathrm{pH}$ was 10 (RSM) and $\mathrm{pH} 5$ (RPH) for Methylene Blue. Similarly, pH 10 (RSM) and pH 8 (RPH) were optimum for Crystal Violet, respectively. Freundlich isotherm was better fitted for Methylene Blue during adsorption by Raw Saccharum munja and Raw Parthenium hysterophorus.

\section{REFERENCES}

1. A. Demirbas, J. Hazrd. Mater., 167(1-3), 1(2009), DOI:10.1016/j.jhazmat.2008.12.114

2. H. Chen, and J. Zhao, Adsorption, 15(4), 381(2009), DOI:10.1007/s10450-009-9155-Z

3. A.M. Aljeboree, A.N. Alshirifi and A.F. Alkaim, Arabian J. Chem. In Press, (2014), DOI: 10.1016/j.arabjc.2014.01.020

4. G. Annadurai, R. S. Juang and D. J. Lee, J. Hazard. Mater., 92, 263 (2002), DOI:10.1016/S03043894(02)00017-1

5. N. K. Mondal, and S. Kar, App. W. Sci., 8(6), 157 (2018), DOI:10.1007/s13201-018-0811-x

6. D. Pathania, S. Sharma and P. Singh, Arabian J. Chem., 10(1), 1445(2017), DOI: 10.1016/j.arabjc.2013.04.021

7. I. Enniya and A. Jourani, J. Mater. Environ. Sci., 8(12), 4573(2017).

8. M. Abbas, and M. Trari, Process Safety and Environmental Protection, 98, 424(2015), DOI:10.1016/j.psep.2015.09.015

9. I. D. Mall, V. C. Srivastava, N. K. Agarwal and I. M. Mishra, Chemosphere, 61, 492(2005), DOI: $10.1016 /$ j.chemosphere.2005.03.065

10. H. I. Chieng, L. B. Lim and N. Priyantha, Desalin Water Treat., 55, 664(2015), DOI: $10.1080 / 19443994.2014 .919609$

11. L. B. Lim, N. Priyantha, C. M. Chan, D. Matassan, H. I. Chieng, and M. R. R. Kooh, Desalin Water Treat., 57(18), 8319 (2016), DOI:10.1080/19443994.2015.1017740 
RASĀYAN J. Chem.

Vol. 12 | No. 4 |1956 - 1963| October - December | 2019

12. M. K. Dahri, M. R. R. Kooh and L. B. Lim, J. Env. Chem. Engg., 2(3), 1434(2014), DOI: 10.1016/j.jece.2014.07.008

13. M. R. R. Kooh, M. K. Dahri, L. B. Lim and L. H. Lim, Arabian J. Sci. Engg., 41(7), 2453(2016), DOI: $10.1007 / \mathrm{s} 13369-015-1877-5$

14. A. Mittal and J. Mittal, Green Chemistry for Dyes Removal from Wastewater: Research Trends and Applications, 409(2015), DOI:10.1002/9781118721001.ch11

15. M. L. Firdaus, E. Susanti, Ghufira, W. Alwi and E. Swistoro, Rasayan J. Chem., 11(4), 1532(2018), DOI: $10.31788 /$ RJC.2018.1144030

16. M. Mathivanan and S. E. Saranaathan, Rasayan J. Chem., 11(2), 877(2018), DOI: $10.31788 /$ RJC.2018.1122086

17. M. Santhi, P. E. Kumar and M. Sathya, Rasayan J. Chem., 11(4), 1423(2018), DOI: $10.31788 /$ RJC.2018.1143066

18. Y. A. B. Neolaka, E. B. S. Kalla, G. A. Malelak, N. K. Rukman, G. Supriyanto, N. Y. T. Puspaningsih, Rasayan J. Chem., 11(2), 494(2018), DOI:10.31788/RJC.2018.1121994

19. M. Otero, F. Rozada, L. F. Calvo, A. I. Garcia and A. Moran, Dyes and Pigments, 57(1), 55(2003), DOI: $10.1016 / \mathrm{S} 0143-7208(03) 00005-6$

20. Allen, S. A., Chemical Analysis of Ecological Materials, Blackwell, London (1989).

21. H. Freundlich, J. Phy. Chem., 57, 385(1906).

22. M. Arami, N. Y. Limaee, N. M. Mahmoodi and N. S. Tabrizi, J. Hazrd Mater., 135(1-3), 171(2006), DOI: $10.1016 /$ j.jhazmat.2005.11.044

23. M. M. Abd El-Latif and A. M. Ibrahim, Desalin Water Treat., 6(1-3), 252(2009), DOI: $10.5004 / \mathrm{dwt} .2009 .501$

24. P. K. Malik, Dyes and Pigments, 56(3), 239(2003), DOI:10.1016/S0143-7208(02)00159-6

25. M. Mulugeta, B. Lelisa, Mod. Chem. Appl., 2(4), 146 (2014), DOI:10.4172/2329-6798.1000146

26. M. R. R. Kooh, M. K. Dahri and L. B. Lim, Appl. Water Sci., 7(7), 3859(2017), DOI: $10.1007 / \mathrm{s} 13201-017-0537-1$

[RJC-5401/2019] 